\title{
ROMADA BORÇLARIN KAYNAKLARI
}

Yazan : Doçent Dr. Şakir BERKI

(1950 yılı C. VII, sayı : 3-4 Ankara H. F. Dergisinin 378 nci ve müteakip sayfalarındaki yazınu devamudır.)

$3^{\circ}$ ) Satıcı mebiin semerelerini de iade etmekle mükelleftir. İadeye tâbi semereler akdin inikadından sonrakilerdir. Bu, mebiin müşterinin mülkiyetine akdin inikadı anından itibaren geçmiş sayılması prensibinin neticesidir.

Mamafih, semerelerin satıcıda kalması şart koşulabilir, ve bu hal tatbikatta fazlasiyle görülmekte idi. ${ }^{1}$

e) Emptio venditio'nun feshi :

$\left.1^{\circ}\right)$ Kaide :

Modern hukuk hilâfina olarak Roma hukuku mukavelede aksine sarahat olmadıkça, veya mebiin gizli kusurlan bulunmadıça bir tarafm akdi icra etmemesi halinde emptio venditio'nun fesh edilmesini kabul etmez. Bu kaide, şimdi görüleceği üzere, bilhassa zarar nazariyesinde daha açlk surette tebarüz eder.

\section{$2^{\circ}$ ) Hasar nazariyesi :}

Satıcı mücbir sebeple ziyaa uğrayan mebii teslim edemediği takdirde, müşteri mukaveleyi icra, yani semeni eda ile mükelleftir. ${ }^{2}$ Bu kaide tamamiyle müşterinin aleyhine değildi; çünkü, Justinianus hukuku böyle bir halde satıcının zayi olan mebi ile ilgili bütün davalannın müşteriye devredileceğini kabul eder. Bu suretle, satıcı, şey çalınmak suretiyle zayi olmus ise Actio furtiden faydalanacaktır. ${ }^{3}$

1) R. Monier, Manuel t. II, 1944, p: 188, N: 1 .

2) Just, İnst, III, 23, 3: mebi müșteriye devredilmeden evvel satıcınır kusuru haricinde hasara uğrarsa, zarar müşteri aleyhineđir. Klâsik devirde kaide aksine idi: Ed. Cuq, Manuel, 1928, p: 461.

3) Bazı müellifler kaidenin klâsik devirde aksine olduğu, yani şeyin tesliminden evvel vaki hasarın satıcıya ait bulunduğu fikrini gütmektedirler: 
$3^{\circ}$ ) Emptio venditio ecele veya şarta bağh olarak yapılmadıkça, akdin icrası aynı zamanda her iki tarafa da terettüp eder. Aksi takdirde icra eden taraf akdi icra etmeyen tarafa karşı Exceptio non adimpleti contrastus'u, yani icra edilmemiş mukaveleden doğan defiyi dermeyan ederek akdi fesh eder. Klâsik devir hukuku mebïn henüz ödenmemiş se. menin rehni olarak satıcı tarafından alıkonulacağını ve nihayet pignoris capio'nun tatbik olunacağını kabul eder. Semen kısmen eda edilmiş olsa bile hüküm böyledir.

\section{$\left.4^{\circ}\right)$ Semenin edası ve mebiin devri arasındaki ilgi.4}

Semenin eda edilmiş olması, veya eda edileceğine dair kefil gösterilmiş olması devredilen șey üzerinde satıcının mülkiyet hakkının ziỵaı neticesini doğurur. Mebiin mülkiyeti hukuken müşteriye intikal eder. ${ }^{5}$

$5^{\circ}$ ) Mebiye istihkak iddialanna karşı garanti.

Eski hukuk mebiin üçüncü şahıslar tarafından sonradan talep edilmesi ihtimal ve tehlikelerine karşı bir garanti yaratmış değildi. Garanti için ayn bir stipulatio yapılmalı idi.

Klâsik devirde, mebiin asıl maliki tarafından geri alınmak istenmesi veya aynî bir teminata karşılı gösterilmiş olması halinde müşteri éviction tehlikesine maruzdu. Çünkü bu sonuncu halde de mebi ipotekli alacaklı tarafindan talep olunabiliyordu.

Eski hukukda, müşteri sırf satıcının müdahalesi ile mebie istihkaka karşı himaye ediliyordu: mebiin istihkaka maruz olması halinde satıcı müddei yerine geçerek mancipatio ile mebii himaye ederdi A.ksi takdirde satıcı, mebiin iki mislini müşteriye borçlu idi. Bütün bù hususlar Mancpatio muamelesinde (beyi için mancipatio) evelden beyan olunmakta idi. Müşteri Usucapio ile satılan şey üzerinde kirit maliki olunça satıcı bütün bu mükellefiyetten kurtuluyordu. Satılan sey nec mancipi ise

Arno, Théorie del periculum rei venditae (Guirisprudenza Ital, 1897, p: 209 et s. Konst antinovitch, Le periculum rei venditae en droit romain, Lyon, 1923; bazı müellifler ise, kaidenin Klâsik devirđe de Justinianus hukukundakii gibi olduğunu metinler zikri ile ispat etmek meylindedirler: Appleton, Rev. hist. de droit; 1926, p: 375 e ts. ; Ed. Cuq, Manuel, 1928, p: .922.

4) Giffard, Précis, t. II, No: 85, 86 ; J. Wolff, Rev. hișt de droit, 1936, t. 14,4 p: II et $\mathrm{s}$.

5) On iki levha kanunununda mahdut da olsa mevcut bulunan bu kaidenin tarihî tekâmülü için bakınız : Wieacker, Lex commissoria, 1932, p : 8 et $\mathbf{s}$. 
satıcı Traditio muamelesi esnasinda stipulatio rem habere licere ile mebie vaki olabilecek istihkak için teminat veriyordu.

Cumhuriyet sonlannda ve Klâsik devir hukukunda stipulatio mebiin elden çıkmasını garantileyen ve res mancipi'lere şâmil genel ve fazlası ile kullanışlı bir usul haline girdi. Ekseriya, mebie istihkak halinde mebıin iki mislinin müşteriye ödenmesi şartını ihtiva eden stipulatio duplae tatbik edilmekte idi. Bu stipultio'dan başka, mebiye vaki istihkakın garantilenmesi için kefil göstermeyi mutazammın stipulatio secundum mancipium da fazlası ile cari idi. ${ }^{6}$

Klâsik devir hukukçulan bizatihi bey'i aktinin mebiin sonradan istilfkakı tehlikesinin garantisi olabileceğini, bu garantinin bey akdinde mündemiç bulunduğu fikrini kabul ettiler. Ekser beyi akitlerinde var sayılan Stipulatio rem habere licere mebiin istihkakına maruz müşteriye mebiin hüküm anındaki kıymetini iade edilmesi mevzuunu ihtiva ediyordu..

Justinianus hukukunda Stipulatio rem habere licere yerine, bilhassa kıymetli şeyler için, stipulatio duplae caridir. Diğer mebiler için emptio empti kâfi idi. Justinianus hukukunda mebïn elden çımasından ötürî́ mebiin iki misline istihkakın icap ettiren haller yine mevcuttu. Halbuki modern hukuk buna müsait değildir, ancak mebiin elden çlkmasından doğacak olan zarar ziyanın tazmini ile iktifa eder.

$\left.6^{\circ}\right)$ Şeyin gizli ayıplan :

Justinianus hukukuna kadar satıcı şeyin gizli kusurlarmdan ancak hile halinde veya stipulatio veya akdin muhtevası nispetinde mes'uldü.

On iki levha kanunlan şeyin gizli kusurlanın bildiği halde beyi mancipatio'sunda aksine beyanda bulunan satıcıyı mes'ul tutar. Müşteri satın aldığı gayri menkulün aynî irtifakłar ile kısıntılı bulunduğunu fark ederse şikâyete hakhdır. ${ }^{7}$

Klâsik devir başlannda köle ve hayvan satışlannda mebiin gizlí ayplan stipulatio ile garantilenmekte idi. 8

Justinianus hukukunda, Actio empti gizli kusurdan ötürü mes'uliyeti sağlamaya kâfi idi. Dava altı ay içinde açılmalı idi.

6) Lenel, Edictum, 1927, p: 546.

7) R. Monier, Manuel, t. II, p: 204, N: 3 ; p: 205, N: 1 .

8) Kölenin istenilen vasıfda olmayışı, hırsızlıktan ötürü actio noxaliye mevzu bulunuşu akdin feshini ve tazminatı icap ettirir. 
$7^{\circ}$ ) Emptio venditiye eklenen Pactuslar :

Beyi akdinin neticeleri ona eklenen bazı pactus ${ }^{9}$ lar ile değiștirilebilir. Alım satım mukavelesine ek olarak yapılan ehemmiyetli pactuslar şunlardır :

a) Pactum displicentiae :

Müşteriye mebii beğenmediğinden dolayı muayyen bir müddet içinde akdi fesh etme yetkisi veren bir anlaşmadır. Bu pactum bilhassa gizli ayıplardan doğan zaran başka yol ile elde etmek mümkün bulunmadığı hallerde faydalı idi.

b) Lex comissoria :

Semenin vaktinde ödenmemesi halinde bey'i satıcıya fesih etmek hakkı veren bir anlaşmadır.

c) Indiem $\operatorname{adictio}^{10}$ :

Muayyen bir müddet içinde daha fazla semen ve daha mülâyim şartlar ile müşteri bulduğu takdirde satıcıya birinci bey'i fesih imkânı veren bir beyidir.

d) Pactum de retrovendendo :

Satıcıya muayyen bir müddet sonunda semeni iade ederek mebii: geri alma, iştira etmek yetkisini veren bir anlaşmadır. Bu takdirde ikinci bey'in bütün masraflan şimdi müşteri vaziyetine geçmiş olan ilk satıciya aittir.

Sabinus bütün bu pactum'lan beyi ile ilgili talikî şarta benzetir. Julien ise, hakh olarak, bu pactum'lar talikî şarta bağlı anlaşmalar mahiyetinde mülâhaza eder.

Justinianus hukuku, taraflan bu pactus'lar ile beyi akdi arasında muhtar bırakır.

\section{B - Locatio conductio :}

Locatio bir şahıs lehine muayyen bir ücret mukabilinde diğer bir şahıs lehine bir şey vermeyi veya hizmetini veyahut da muayyen bir işi tizerine almasını icap ettiren nzaya müstenit bir akittir.

9) Kısım, Fasıl.

10) Senn, Nouv. rev. hist. de droit, 1913, p: 275 et $\mathbf{s}$. 
a) Locsatio'nun tarihçesi :

En eski hukukda icar peşin idi: icar bedeli şeyin teslimi anında verilmeli idi .

En eski Romada ancak hayvan ve köle ican tatbik edilmekte idi. Diğer locatio çeșitleri M. E. 2 nci asır başlannda belirir. ${ }^{11}$

Roma yabancilar ile dolmaya başladığı zaman kira akdinin çeşitleştiği görülür. Nihayet, büyük arazi sahipleri fakir köylüye arazi kiralamakda idiler.

M. E. 2 nci asir ortalannda Romada bütün locatio tipleri tatbik edilmeğe başlar. ${ }^{12}$

Quintus Mucius Scaevola devrinde (M. E. 94) icar akdinin hukukì müeyyidelere bağlandığı mevsuktur: Actio locatio, Actio conducti. Birincisi locator, ikincisi conductor lehine verilmiştir.

b) Locatio tipleri :

$\left.1^{\circ}\right)$ Locatio rei (şeyi ican) :

a) Tarif :

Locator'un muayyen bir şeyden muayyen bir müddet ve muayyen bir ücret mukabilinde faydalanmasını sağlayan bir icardır.

Locatio rei'nin mevzuu menkul ve gayri menkul olabilir. Locatio rei de akitlerin teşekkülü için gerekli şartlarla teşekkül eder.

Kira bedeli beyide olduğu gibidir: muayyen olmalı ve para ila gösterilmelidir. ${ }^{13}$ Tabiî semerelerin bir kısmı da icar bedeline karşıllı tutulabilir. ${ }^{\text {it }}$

Locatio rei iki tarafa vecibe doğuran mükemmel bir akittir; binnetice, akdi nteşekkülü anında her iki taraf borç altına girer: kiraya veren paestare rem, yani şeyin teslimi ile ; praestare rem için tradiito kâfidir, çünkü kiracı alelâde vazulyed durumuna geçecektir, çılak mülkiyet kiraya verende kalır, binnetice, zilyedliği himaye eden interdictum'lardan faydalanacak olan da locator, yani kiraya verendir.

11) Ed. Cuq, Manuel, 1928, p: 477 ; Huvelin, II, 1929, p: 94 et s.

12) Georgesco, Rapports de la philologie et du droit romain, 1934, p: 12 et $\mathrm{s}$.

13) Justinianus hukukunda icar bedelinin mutlaka para olarak tespiti zaruri değildir: Longo, Mélanges Girard, II, p: 105 et s.

14) Girard, Manuel, 1929, p: 605, N: 1. 
Locator'un ikinci mükelefiyeti şeyi kiracının faydalanabilmesine daima amâde bulundurmaktır; netice itibariyle, șeyin bakımına itina edecektir; tamir ona aittir; şeyin gizli kusurlarından mes'uldür.

Justinianus hukukunda, locator bilmesine imkân bulunmayan giłli kusurlardan da mes'uldür. ${ }^{15}$ Nihayet; conductor'un zaruri masraflarını tazmin mükellefiyeti de mevzu bahistir.

Conductor'un esaslı borcu icar bedelini eda ${ }^{16}$ ve bu vade hululünde şeyi iyi bir halde iadeden ibarettir.

b) Locatio rei'nin son bulması :

Mandatum ve societas gibi kiraya verenin şahsı ile alâkadar bulunmadığından, locatio rei kiralayanın ölümü halinde sukut etmez: kiralayanın hak ve mükellefiyetleri mirasçlanna geçer.

Locatio rei vâdeye bağh değilse taraflardan birinin iradesi ile her zaman fesh olunabilir. Vade umumiyetle beş senedir. Locatio müddete tâbi değilse fesih için iki tarafın uzlaşması lâzımdır.

c) Locatio rei'nin mahiyeti :

Locatio rei zahiren usufructus'a benzemekte ise de, usufructus aynî, diğeri şahsî hak doğurur. Netice olarak, locator şey üzerindeki hakkin herkese, ve bilhassa, şeyin ikinci malikine karşı dermiyan edemez: kiraya veren, şeyin mülkiyetini başkasına devretmek suretiyle locaito rei son bulmuş olur. Modern hukukda ise vaziyet aksinedir: şeyin vadeye bağlı ican şeyin ikinci malike geçmiş olması halinde de berdevamdır ; mamafih, locator Romada zarar isyan talebine haklıdır. ${ }^{17}$

Yukan Imparatorluktan itibaren locatio rei'nin klâsik prènsiplere zıd inkişaflara uğradığı görülüyor : Caracalla, ecele bağlı olsa bile locatio rei'nin, kiraya verenin şeye ihtiyaç hissettiği takdirde, her zaman fesholunabileceğini kabul eder.

$\left.2^{\circ}\right)$ Locatio oprerarum (Hizmet akdi)

Bir ücret mukabilinde bir şahsın (ekseriya işȩi) iş verene muayyen bir is yapmasmı mevzu edineñ nzầ bir mukaveledir.

15) Huvelin, Cours, t. II, p: 130 et s.

16) Icar bedelini eda nispeti şeyden faydalanma haddi ile tayin edilir:

R. Monier, Manuel, 11944, p. II, p: 223, N: 2.

17) Julianus, D. 19,2 , fr. $25,1$. 
Romada hizmet akdine fazlası ile tesadüf olunmamakta idi. Çünkü pater bilhassa azâdlı kölesinin operae'sı ile iş ihtiyacını sašlamakta idi. Diğer cihetten, kölelerin azim faaliyeti de ehemmiyetli idi.

İşçi (locator) işi uyuşulan müddet içinde başarmalıdır ; ücrete defaten müstahaktır ${ }^{18}$. Ücret ekseriya haftada bir ödenir.

$3^{\circ}$ ) Locatio operis faciendi. (İstisna akdi)

Bir şahsın (conductor) diğer bir şahsa (locator) muayyen bir işı bu berikinin vereceği malzeme ile ve bir menfaat karşlığında taahhüt etmesidir. Bir şahsın diğerine nakletmek üzere eşya devri, ev yapılmak için malzeme vermesi bu tip locatio'nun mevzuunu teşkil eder.

Malzeme conductor tarafindan tedarik ediliyorsa locatio, beyi akdini de ihtiva eden bir location operarum'dan ibarettir. ${ }^{19}$

Deniz nakliyatı da locatio operis faciendi mevzuuna dahildi. ${ }^{20}$

Deniz nakliyatını mevzu edinen locatio operis faciendi hususi prensiplere bağlanmış idi. Bu hususivetler arasında bilhassa modern Avarya'nın temelini atmış olanı ehemmiyetlidir : Bütün Akdenize hâkim olan Lex Rhodia de Jactu (Rodos adası kanunu) ${ }^{21}$ Avaryaya temel olan kaideyi şöyle izah eder : furtına vesaire gibi tehlikeler karşısında kaptan tarafından denize atılan eşya diğer bütün nakliyat sahiplerini müsavatan mülzem kılar.

Emtia sahipleri kaptan ile yapmış olduklan locatio operis faciendi gereğince kaptana (Magister navis) actio locati'yi açmak suretiyle tazmin talebinde bulunurlar. Kaptan da actio conducti ile eşyasi kurtulmuş olan emtia sahiplerine rücu eder.

\section{C - Societas (Şirket akdi) :}

Şirket akdi en az iki şahsın kazanç temini ve kazancın aralannda taksimi için ortaya bir şey koymalannı icap ettiren nzaî bir akittir.

18) Mamafih, is kenđi kusuru ile inkitaa uğradığı hallerde hüküm böyle değildir: P. Laborderie, Rev. général de droit, 1909, p: 192 et $\mathrm{s}$.

19) Ga)ius, Inst. III, 147 ; Erman, Rev. Général du droit, 1892, p: 327 et $\mathbf{s}$.

20) Lex Rhodia: Ed. Cuq, Manuel, 1928, p. : 488 et s; Huvelin, Etude d'hist du droit commercial romain, 1929 , p: 184 et s; R. Monier, t. II, p: 227, N: 4.

21) Palaszo, Lex Rhodia, 1919. 
a) Societas'm tarihçesi.

Gaius societas'ın en eski tipi olarak müşterek mirasçılar arasındakı Consortium'u göstermektedir. Bununla beraber rıaya müstenit şirket akdi ile kardeşler ve dostlar arasındaki iştirâk arasında ehemmiyetli farklar vardır ; çünkü, societas jus gensium, consortium ise jus civile müessesesi idi. Netice itibariyle, consortium'a aykırı olarak, societasda her şerik diğerleri namına sermayeyi devredemez ve onlar namına sermaye iktisabına ehil değildir. ${ }^{22}$

Roma hukuku tam mânası ile şirket akdini M. E. 2 ci asırda idral: etti. ${ }^{23}$

b) Societas çeşitleri.

Klâsik clevir hukukunda societas şu tiplere ayrilır :

$\left.1^{\circ}\right)$ Societas Omnium bonorum. ${ }^{24}$

Şeriklerinin mevcut ve gelecekteki bütün mallarını ortaya koymalannı icap ettiren bir şirket akdidir.

$2^{\circ}$ ) Societas alicusus negotiationis. ${ }^{25}$

Muayyen bir işin başarılması için kurulan şirkettir. İşçilerin bir hasadı kaldırmalan için yaptıklan şirket böyledir. ${ }^{26}$

$3^{\circ}$ ) Societas quaestus.

Şeriklerin bütün mamelekini değil meslekî kazançlarının bir araya getirilmesini icap ettiren şirket akdidir. Mukavelede sarahat bulunmayan hallerde bu societas tipi için mukaveleye girişilmiş olduğunu farz ve kabul edilir. ${ }^{27}$

$4^{\circ}$ ) Societas'ın mahiyeti ve teşekkülü.

Şirket akdi şu şartlann mevcudiyeti ile teşekkül edebilir : hissedar-

22) Teferruat : Lévy-Bruhl, Le Consortium artificiel du nouveau Gaius, $1930, \mathrm{p}: 293$ et $\mathrm{s}$.

23) Tite-Live, 23, 48, $49: 210$ yıllarında İspanya ordusunun iaşesini üzerine alan üç şirket faaliyete geçmişti.

24) Lenel, Das Edictum, 1927, p : 297.

25) Gaius, Inst. III, 148.

26) Hellebrand, F. Koschaker, III, p : 259 et s.

27) $\mathrm{Bu}$ şirket akdine hibe ve sair gibi sonradan hükümden düşmesi muhtemel bulunan hukukî kıymetler hisse olarak konulamaz : Paul, D. 17, 2, fr. 71,1 . 
ların rızası, hisse koymalan ve kazancı paylaşmalanı şarttır. Hissenin mutlaka para olarak tespitine lüzum yoktur. Kârdan mahrumiyet şirket akdinin butlanını doğurur.

Şirket akdinin mevzuu meşru olmalıdır : yol keserek kâr edinmek gayesi ile birleşmek şirket akdi değildir.

$2^{\circ}$ ) Societas'in hukukî mahiyeti.

Sirket akdi ortakların karşlıklı itimadına dayanır, binaenaleyh, şeriklik başkasına devir edilemez ve bir şerikin ölümü veya Capitis de. minitio'ya maruz kalması halinde mirasçları onu temsil edemezler. ${ }^{28}$

d) Societas'ın hüküm ve neticeleri.

İki tarafa da vecibe yükleyen tam bir akit olan şirket akdinin hüküm ve neticeleri şöylece formüllenebilir : her şerikin hak ve mükellefiyetleri aynı olduğundan societas'ın müeyyidesi tek bir davadır : Actio pro socio.

$\mathrm{Bu}$ dava formülünün condamnatio kısmmda şerikin ancak gelir kaynakları nispetinde mahkûm, mes'ul edileceği kaydedilir. Dava, so. cietas itimada müstenit bir mukavele olduğundan, terzil edicidir.

Justinianus hukukunda her şerik şirket emvalini kendi mallan imiş gibi idare ile mükelleftir.

Modern hukuka aykm olarak Roma hukukunda her ortak kâr ve zarara müsavat üzere iştirâk eder. Mamafih, mukavelede aksine hüküm bulunabilir.

e) Societas'in sukutu.

Ortakların tabiî ve hükmî ölümü, müddetin geçmesi, gayenin tahakkuku ile şirket akdi son bulur.

Modern hukukun hilâfına olarak tek bir şerikin feragatı da societas'in sukutuna sebeptir. ${ }^{29}$

\section{D - Mandatum (Vekâlet akdi)..$^{30}$}

Bir şahsın (Mandator) diğerini ücretsiz olarak kendi menfaat ve namına bir şey yapması, bir hukukî muameleye girişmesi için memur etmesidir.

28) F. Desserteaux, Capitis deminitio, II, $1919, \mathrm{p}: 165$ et $\mathrm{s}$.

29) Gaius, III, 151.

30) Le Bras, L'Evolution du procurateurs, thèse ,1922, p : 102 et s. 
a) Mandatum'un tarihçesi.

Klâsik devrin sonuna kadar mandatum ancak muayyen işler için makbuldü. ${ }^{31}$. Klâsik devir sonlarnda genel mandatụm nazariyesi vücut buldu. Bu umumî vekâlet yanında hususî vekâlet de yürürlükte idi: beyi akdi, davada vekâlet özel mandatum'a dahildi.

Justinianus hukukunda umumi vekil Procurator omnium bonorum, özel vekil procurator unius rei adı ile anılır. Justianus hukukunda umc:mî vekil her işe, hukukî muameleye yetkili değildi ; bazı işler için umumî vekilin özel vekâlet alması lâzımdı : müvekkilin mahkemede temsilinde hal böyledir. Buna mukabil ; Justinianus hukuku mefruz vekâlete (Mandatum praesumtum) de yer verir. Paterin, vasinin vekâlet,, akrabaların birbirini temsili bu vekâletin misalleri arasındadır.

İmparatorluk hukuku vekâlette ücreti de kabul eder. Ancak actio mandati ücretin istihsalini sağlamaz.

b) Mandatum'un teşekkül şartlar.

$\left.1^{\circ}\right)$ Taraflar nza göstermelidir.

$2^{\circ}$ ) Mandatum prensip itibariyle mandator menfaatine netice dogurmalıdır. ${ }^{32}$

$3^{\circ}$ ) Mevzu gayri meşru olmamalıdır. ${ }^{33}$

c) Mandatum'un mahiyeti ve neticeleri.

$\left.1^{\circ}\right)$ Mandatum'un maihyeti.

Justinianus hukukunda mandatum iki tarafa vecibe yükleyen nakıs akitler kategorisindendir ; çünkü akdin teşekkülü anından itibaren vekil havale edilen işi derhal ifaya başlamakla mükelleftir. Bu mükellefiyet actio mandati directa ile müeyyidelenmiştir ; mandator ise ancak havale edilen işin bitmesi anında mükellefiyet altına girebilir : vekilin mandatum dolayısiyle yaptığı zarưî masraflan tazmin ile mükellef olabilir. Bu mükellefiyet de vekil tarafindan açılacak olan actio mandati contraria ile müeyyidelenmiştir.

31) Ed. Cuq, Manuel, 1928, p : 489.

32) Mamafih, ileride görüleceği üzere, üçüncü şahıs menfaatı ile ilgili mandatum da muteberdi.

33) Paul, D, 17, 1, fr. 1, 4. 
$2^{\circ}$ ) Mandatum'un hükmü.

Vekâlet dostluk münasebetine müstenit bir vazife olduğundan emniyeti, itimadı suiistimal eden vekil terzil edici mahkûmiyete maruzdur. ${ }^{34}$

Roma hukukunda prensip temsil yokluğu olduğundan vekilin yaptı̆̆ı muamelâtın hüküm ve neticeleri doğrudan doğruya mandator'u ilgilendirmez. Bu neticeleri vekil mandator'a bilâhara, işin bitmesinden sonra, devre, mandator da bu neticeleri kabule mecburdur.

Vekil vekâlet akdinin verdiği yetki gereğince hareket etmekle mükelleftir. Aksi takdirde mandator mandatum neticelerini kabule mecbur değildir. Mamafih, Proculien mektebi fikrine itibar eden Justinianus hu$\mathrm{kuku}^{35}$, fazla semen ile alınmıs şeyin, vekil semen fazlalığını üzerine aldığ

d) Mandatum'un sukutu.

İşin ifa edilmesi veya ifanın imkânsızlaşması, mandatum itimada müstenit akit olduğundan vekilin ölümü, vadeye bağlı mandatum'larda vadenin hululü, ișe bașlamadan evvel mandator'un cayması mandatum' un sukutu sebepleridir. Taraflardan birinin ölümü de fesih sebebidir. ${ }^{36}$

5. İsimli ve isimsiz akitler. ${ }^{37}$

\section{A - İsimli mukaveleler.}

Rehin müstesna, buraya kadar gözden geçirilmiş olan akitler jus civile'nin tanıdığı hüsnüniyet mukaveleleridir. Bu akitlerden her biri hususî içtimaî ve iktisadî gayelerin tahakkukuna yarar, ve her biri özel prensip ve kaidelere tâbidir. Bu akitler jus civile'ce ayn ayrı isim taşıdıklanndan isimli mukavele kategorisine dahildirler.

\section{B - Isimsiz mukaveleler:}

Jus civile'nin ayn ayn isimlendirdiği akitler gurubuna girmeyen mukavelelere isimsiz mukaveleler denir. İsimsiz mukaveleler iki tarafa dá

34) Gaius, Inst, IV, 182.

35) Just, Inst. III, 26, 8.

36) F. Dessertaux, Capitis deminitio, II, 1, 1919, p : 242 et s.

37) Meylan, Origine et nature de l'action praecriptis verbis, thèse, Lausanne, 1919 ; Giffard, Précis, 1938, p : 147 et s. 
vecibe doğurur ve mukaveleyi icra eden tarafa diğerini de ifaya mecbur etme yetkisini verir.

Isimsiz mukavelelerin müeyyidesi isimlilerin müeyyidesi gibi iki dava ile temin edilmiş değildir. Bir tek dava hem alacaklı ve hem de borçlu leh ve aleyhine işler. Ekseriya actio praecriptis verbis isimsiz mukavelelerin müeyyidesi idi.

a) Isimsiz akitlerin tasnifi.

İsimsiz mukaveleler mevzulan itibariyle dört tip gösterirler :

$\left.1^{\circ}\right)$ Do ut des.

Bir şeyin nakline mukabil diğer bir şeyin naklini konu edinen isim. siz mukavelelerdir. Trampa (Permutaio) bunlann tipik misalidir.

$2^{\circ}$ ) Do ut facias.

Bir şeyin verilmesine mukabil bir şey yapılmasını mevzu edinen mukaveledir. Mükellefiyet yükleyen hibeler bunlann misalidir.

$3^{\circ}$ ) Facio ut des.

Bir şeyin yapılmasına karşlık bir şeyin mülkiyetinin devrini konu edinen isimsiz mukavelelerdir.

$4^{\circ}$ ) Facio ut facias.

Bir işin yapı'masına karşılık bir işin yapılmassını mevzu edinen mukavelelerdir. ${ }^{38}$

b) Hususiyet gösteren isimsiz mukaveleler.

Ehemmiyetli isimsiz mukavele tipleri șunlardır :

$1^{\circ}$ ) Trampa (Permutatio).

Emptio venditio'ya benzeyen, ve fakat isimsiz mukavele prensiplerine tâbi olan ${ }^{39}$ trampa emptio venditio'dan şu suretle ayrilır : bey'i akdi sırf iradelerin uzlaşmas $s_{1}$ ile teşekkül edebileceği halde trampa şeyin devrini de icap ettirir ; trampada başkasına ait şey devrolunamaz, binnetice, taraflar şeyin yalnız zilyedliğini değil mülkiyetini de nakletmekle mükelleftirler. ${ }^{40}$

38) Isimsiz mukavelelerin bu tasnifi Paulus'a atfedilmekte ise de, aksi mâna için bakınız : F. Koschaker, I, 1939, p : 70 et s.

39) Just, İnst,. III, 23, 2.

40) D. 19,4 , fr. $1,3$.

A. Huk, F. Der. 
Emptio venditio ile permutatio'nun hükümleri bakımından en ziyade yaklaştıklar cihet şeyin gizli ayıplan ve mebiin sonradan istihkak davasına maruz kalacağı meselesinde göze çarpar.

\section{$2^{\circ}$ ) Donation sub modo (ivazlı hibe)}

Vahip muayyen bir şeyi hibe ederken kendisine hibe yapılan şahsın da hibeye karşllık olarak ya kendisine veya üçüncü bir şahsa bir şev vermesini, bir menfaat temin etmesini şart koşabilir.

\section{$\left.3^{\circ}\right)$ Transactio.}

İhtilâflı bulunan bir șeyden ona muadil diğer bir șeyin verilmesi vadine mukabil vaz geçilmesini icap ettiren bir anlaşmadır. Stipulatio ile yapılmış olduğu hallerde actio praescriptis verbis transactio'nun müeyyidesi olarak kullanılır. ${ }^{41}$

\section{$4^{\circ}$ ) Aestimatum. ${ }^{42}$}

Romada ziyadesi ile tatbik edilen aestimatum pretöre müracaat olunarak bir hukukî muamelenin hangi akitler zümresine dahil olduğunu formül ile tespit ettirmektir.

\section{$\left.5^{\circ}\right)$ Precarium.}

İlk zamanlarda akit kategorisine dahil olmayan precarium patrisiyenlerin arazilerini ivazsız olarak ve fakat her zaman geri almak kaydı ile terk etmeleridir.

Klâsik devirde precarium'un müeyyidesi yalnız interdictum de procario idi. Arazi sahibi lehine işleyen dava ancak Așağı İmparatorlukta yaratilabildi. ${ }^{43}$

Justinianus hukukunda precarium facio ut facias gurubuna giren isimsiz mukavelelerdendir.

6. Hüsnüniyet ve kat'î hukuk mukaveleleri.

İade ve bilhassa tazminatın şumulünü tayin ile sıkı sıkıya ilgili olan mukavelelerin bu tasnifi şöyle izah olunur : Bazı mukaveleler vardır ki yerine getirilmedikleri vakit borçluyu metinlerindeki sarahata göre tazmin ve iade ile mükellef kılarlar. Bu gibi mukavelelerde hâkim nasafet

41) Caudemet, Rév. hist. de droit, 1937, p : 519 et $\mathrm{s}$.

42) Just, Inst. IV, 6, 28 ; Rev. hist. de droit, 1933, p : 217.

43) R. Monier, Manuel, t. II, 1944, p : 250, N: 2. 
kaidesini tatbik sureti ile tazminatı indiremeyeceği gibi, hüsnüniyet ve sui niyet nazariyesinden hareket ederek iade mükellefiyetini azaltıp çoğaltamaz. SSekle bağh aktlerin hemen hepsi kesin hukuk mukavelelerindendir. Bu gibi mukavelelerde hâkim, prensip itibariyle, dolus, metus gibi nzayı ifsad eden sebepleri de nazarda tutarak hükmedemez.

Tazminat ve iadenin ve hattâ ifanın şumulünü hüsnüniyet, suiniyet ve nasafet prensipleri çerçevesinde tayinine mütehammil olan mukaveleler hüsnüniyet mukaveleleridir. Bunlar hâkime hile ikrah ve hatâ gibi iradyi bozan sebepleri de göz önünde bulundurma hakkını verirler.

$\mathrm{Bu}$ mukaveleler jus civile ve jus honorarium davalan ile müeyyidelenmişlerdir. hildir.

Aynî mukavelelerin hepsi hüsnüniyet mukaveleleri gurubuna da-

7. Bir tarafa ve iki tarafa vecibe yükleyen akitler.

(Contrats synallagmatiques)

A - Bir tarafa vecibe yükleyen akitler.

Akit yapıldığı andan icrasına kadar yalnız bir tarafı borçlu, diğerini alacakl knlyyorsa bir tarafa vecibe tahmil eden akittir. Bu gibi akitlere contrats unilatéraux denir. Ödünç akdi, bilhassa mutuum bunun tipik misalidir.

\section{$B$ - Iki taraft da borçlu kilan akitler.}

Bunlar her iki tarafı da borçlu vealacaklı kılan mukavelelerdir. Emptio venditio bu tip akitlerin tipik misalidir : satıcı şeyi (mebi) devir mükellefiyetine karşlık semeni alma hakkına, müşteri semeni edaya karşllk mebii isteme hakkına sahiptir.

İki tarafa vecibe yükleyen akitler de iki çeşittir:

a) Ilki tarafa da mükellefiyet yükleyen tam akitler.

(Contrats synallagmatiques parfaits).

Bu akitler yapıldığı anda her iki taraf da hak ve borca sahip olur. Beyi akdinde akdin inikadı aninda semen ve mebiin teslim borcu ve bunlan isteme hakkı doğmuş olur. İcar akdinde de hal böyledir.

b) İki tarafa vecibe yükleyen nakıs akitler.

Bunlar teşekkülleri anında bir tarafa, bilâhara diğer tarafa vecibe doğuran akitlerdir. 
Mandatum ve quasi contractus'lardan vesayet ve fuzulì vekâlet butip mukavelelerdendir. Çünkü bu akitlerde akdin teşekkülü anında mükellefiyet evvelâ vekile, vasi ve fuzulî vekile terettüp eder. Yapılan mükavele sonunda zarurî masraflara girişilmiş ise müvekkil, küçük veya kadın, ve, fuzulì vekâletten faydalanan (dominus) bu masrafların tazmini ile mükellef olacaklardır.

\section{DÖRDÜNCÜ FASIL}

\section{ŞIBIH CÚRỪ VE ŞIBIH AKITLLER}

\section{(Quasi ex delicto - Quasi ex contractus)}

\section{1 - Quasi ex delicto (şibih cürüm)}

Justinianus borç kaynaklan arasında dört tip quasi delicto'dan bahısetmektedir: ${ }^{44}$

1. İhmal, hile vesair sebeplerle yanlış hüküm veren hâkim şibih cürüm işlemiş sayllır. Bu takdirde haksız ve yanlış hükümden zarar görmüş olan şahıs hâkim aleyhine dava açabilir. Dava pretör tarafından verilir.

2. Evinin dışına veya penceresine bir şey asıp bunun düşmesi ile yolculara zarar vermiş olan şahıs quasi ex delicto failidir ve aleyhinde actio de positis açlır. Bu dava herkes ve ekseriya ilk geçen ve zarar gören tarafından açlır.

3. Pencereden bir şey atmak veya su boşaltmak suretiyle yolculara zarar veren ev sahibi şibih cürüm işlemiş sayllır ve kusuru olmasa dahi davaya maruz kalır.

4. Otel, gemi ve han sahiplerinin işçileri tarafindan müşterinin malına karşı yaptıklan hırsızlık veya verdiği zararlar da quasi ex delicto'yä dahil olup, sahip actio furti ve damni'ye maruz kalır. ${ }^{45}$

II - Quasi ex contractus. ${ }^{46}$

44) Gaius ; D. 44, 7,5 ; Just, Inst. IV, 5; Lenel, Edictum, 1927, p : 167 et s. Mesuliyet habitator'a, yâni kiracıya düşer.

45) Teferruat : Ed. Cuq, Manuel, 1928, p : 589; Giffard, Précis, t. II, 1934, p : 223, No: 386.

46) Just, Inst, III, 27. 
I. Quasi ex contractus'un tarifi.

Taraflann peşinen nzalanı icap ettirmeyen ve fakat actio rei persecutoria'ya mahal veren, yani aynen contractus'lar neticesini doğuran hukukî muamelelere şibih akit denir.

2. Quasi ex contractus çeşitleri.

A - Haksiz mal iktisabr.

$B$ - Fuzuli vekâlet.

A - Haksz mal iktisabr:

Roma hukuku başkasına ait bir şey veya kıymeti mamelekine geçirmeyi veya bir şeyi sebepsiz yere elinde bulundurmayı haksız ve sebepsiz mal iktisabı nazariyesi içinde mütalâa eder.

M. S. II nci asır sonlanna kadar çeşitli davalarla müeyyidelenmiş olan iade mükellefiyeti bu asırdan itibaren condictio incerti ile daha şamil bir şekilde müeyyidelenmiş oldu.

a) Haksız ve sebepsiz iktisabın çeşitleri.

Cumhuriyet devri sonlan ile Yukan İmparatorluk devrinde iki tip haksız iktisap mevcuttur :

$\left.1^{\circ}\right)$ Condictio ex causa furtiva. (Gayrn şeyini haksız yere elde bulundurmak).

Müelliflerin ekserisi ${ }^{47}$ Sabinus'dan müktebes ${ }^{48}$ bir metne dayanarak condictio ex causa furtiva'nun bir şahsa ait şeyi haksız yere elinde bulundurmanı mutuum ve permutatio hallerine de şamil bulunduğu fikrindedirler.

$2^{\circ}$ ) Codictio ob rem dati.

$\mathrm{Bu}$, bir şey temini maksadı ile verilmiş olan ve iade edilmeyen şeylerin iadesini temin eden bir davadır. Hibe müstesna ${ }^{49}$, hukukçular bu gibi şeylerin geri alınabilmesini kabul ederler. Çünkü kendisine bir şey temin etmesine karşılık olarak para veya bir şey verilmiş olan ve

47) Ed. Cuq, Manuel, 1928, p : 535 ; Girard, Manuel, 1929, p : 653, n: 3. Aksi mânada : Huvelin, Furtum, 1915, $\mathrm{p}: 338$ et $\mathrm{s}$.

48) D. 12,5 , fr. 6.

49) R. Monier, Manuel, t. II, 1944, p : 278, N: 1.

Temin edilmek istenilen şeyin imkânsız hale girmesi de condictio'ya mahal verir : D. 12,6 , fr. 53 . 
istenilen şeyi temin etmemiş bulunan şahıs haksız ve sebepsiz yere zenginleşmiş olur.

\section{$3^{\circ}$ ) Condictio indebiti.}

Borçlu olunmayan şeyin hâta ile ödenmiş olması halinde sebepsiz yere mamelekini arttırdığından accipiens'in iade ile mükellefiyetini Roma hukuku kabul eder. ${ }^{50}$

Condictio indebiti, Ulpianus ${ }^{51}$ in hilâfına olarak Gaius $^{53}$ ca borç ödeyen ile accipiens arasındaki ilgiyi bir mukavele gibi değil, bilâkis bir hukukî münasebeti bertaraf eden bir münasebet olarak mütalâa etmektedir.

b) Justinianus hukukunda condiction çeşitleri.

Justinianus hukukunda condictio ex causa furtiva, ve klâsik devirde bundan farksız olan condictio ex injusta causa ve nihayet condictio indebiti rollerini muhafazaya devam etmektedirler.

Klâsik devirden farklı olarak, Justinianus hukukunda İmparatorlarca kabul edilmiş olan pactus'lardan doğacak olan haksız iktisapların müєyyidesi olan condictio ex lege yürürlüktedir.

Nihayet, condictio ob turpem causam ve condictio sine causa animalıdır. ${ }^{54}$

Bunlardan bilhassa akdî saha haricinde tatbik sahası bulmuş olan condictıo'ları sırası ile gözden geçireceğiz :

$\left.1^{\circ}\right)$ Condiction indebiti. 55

Justinianus hukukunda borçlu olunmayan şeyin edas 1 quasi ex contractu'dan doğan bir borç meydana getirir : ödenen șeyin iadesi.

Condictio indebitı için şu şartlar lâzımdır : accipiens ve tradens in hatâ ile hareket etmiş o!malan lâzımdır. Aksi takdirde, yani bilerek

50) Huvelin, Furtum, p : 632.

51) D. 12, 6, fr. 2, pr.

52) D. 12,6, fr. 33

53) Gaius, İnst., III, 91 ; Ed. Cuq, Manuel, 1928, p : 539, N: 9.

54) Meuman, La théorie de l'enrichissement illégitime en droit justinien (Stud. Riccobo, IV, p : 453.)

Hıristiyanlığın tesiri ile bazı condictio tipleri de yaratıldı :

Rev. d'hist. du droit, 1929, p : 57 .

55) Ed. Cuq, Manuel, 1928, p : 542 et s. 
eda ve kabul halinde, accipiens hırsı, trandens vahip muamelesi görür. 56

$2^{\circ}$ ) Condictio ob injustum causam.

Kanumî faiz haddinin müeyyidesi olan bu condictio fazla eda edilen faiz mikdannın geri alınmasını temin eder.

$3^{\circ}$ Condictio ob turpem causam.

Ġayri ahlâkî ve kanunî maksatlar için verilmiş şeylerden faydalananlar aleyhine verilen condictio tipidir. Cürüm işlenmemesi veya çalınmış bir şeyi iade etmek için alınmış para veya eşya bu condictio ile geri alınır.

$4^{\circ}$ ) Condictio sine causa.

Bir şahsa teslim edilip de teslim edilen kimse tarafindan haksız yere faydalanılan şeyin geri alınmasını sağlayan condictio'dır. Semeni eda eden müssteri bu condictio ile pey akçesini geri alabiliyordu.

c) Roma hukukundaki haksız mal iktisabı ile modern haksız mal iktisabı arasındaki fark.

Buraya kadar anlatılanlardan Romada haksız mal iktisabının modern hukukta olduğu gibi bir nazariye haline getirilmemiș olduğu anlaşlır. $\mathrm{Bu}$, Justinianus hukukuna bile condictio'lann ayn ayn sayılmı olmaları ve bilhassa haksız mal iktisabı için ona tekaddüm eden bir hukukî muameleye lüzum olması kaidesinin mevcudiyeti ile kolayca anlașilır. ${ }^{57}$

\section{B - Negotiorum gestio (Fuzulî vekâlet) 58 .}

Bir şahsın diğeri tarafından yetkili kalınmaksızın onun menfaatına hukukî muamelelerde bulunması fuzulî vekâlettir. Bu suretle muameleye girişene Negotiorum gestor (fuzulî vekil), namına muameleye girişilene de dominus denir.

a) Negotionum gestio'nun tarihçesi.

Mandatum ve negotiorum gestio'nun çeşitli devirlerde bir arada tat-

56) Huvelin, Furtum, p: 498

57) D. 12,6, fr. 33.

58) Frese, Mẻlanges Cornil, I, 1926, p : 327 et s; G. Le Bras, L'évoJution générale du procurateur en droit privé romain, dès origines du 3 ème siècle, Paris, 1922. 
bik sahasında bulunmuş olmaları negotiorum gestio'nun tarihçesi bahsinde hayli güçlükler doğurur. 59

Üzerinde ittifak edilen cihet Mandatum'un negotiorum gestio'dan. daha evvel tatbik edilmekte olduğudur. ${ }^{60}$

Negotiorum gestio'yu ilk defa müeyyideleyen pretör hukukudur. Pretör, peşinen selâhiyetlenmemiş olduğu halde başkasının işlerini çevìren şahısla (negotiorum gestor), işi görülen kimse (dominus) aras $\mathrm{s}_{10}$. daki münasebeti tanzim edici in factum davalar bahşediyordu. Muallâkta kalan terekenin idarecisi veya gaibin mallann idare eden ile gaip ve mirasçmın bunlar ile olan münasebeti bu suretle tanzim olunmakta idi.

b) Negotiorum gestio'nun şartlarn.

Fuzuli velkâlet mevzuubahis olabilmek için Roma şu şartları derpiş eder :

$\left.1^{\circ}\right)$ Başkasının işlerine hakikî, fiilì bir müdahalede bulunmuş olmak lâzımdır. ${ }^{61}$ Binaenaleyh, negotiorum gestor'un başkasının iși ile uğraștığını bilmesi lâzımdır ; dominus'un şahsında hatânın ehemmiyeti yoktur.

$2^{\circ}$ ) Negotiorum gestor'un animus obligandi'ye, yani yaptığı zarurî masrafları dominus'a ödetme niyetine sahip olması gerekir. ${ }^{62}$

$3^{\circ}$ ) Klâsik devirde negotiorum gestor'un mutlaka dominus'un kim olduğunu bilmeksizin hareket etmesine lüzum yoktur. Dominus'un negotiorum gestio'ya muhalefet etmemesi halinde de fuzulî vekâlet mutcberdir. ${ }^{63}$

Dominus'un fuzuli vekâletten haberdar olmayışının șart haline g:rişi daha sonraki devirlerde belirir. ${ }^{64}$

c) Negotiorum gestio'nun netice ve müeyyidesi.

59) Albertario, Stu. et. Documenta, 1936, p: 12 et $\mathbf{s}$.

60) R. Monier, Manuel, t. II, 1944, p: 271, N: 3.

61) D. 3,5 , fr. 5,4 ; D. 47, 5, fr. 9.

62) Paul, D. 10, 3, fr. 14.

63) Bazı müellifler (Klụber, Z. der sav. stift, t. 38, p: 197.) aksi fikri gütmekte iseler de, fuzulî vekâletin tarihçesi bunu cerhe kâfidir. Nihayt, Roma hukukunda zımnî mandatum mvcudiyetini gösterir metinler bulunmayışını, ve nihayet, Digesta'nın müspet mütalâayı teyit eden hükmünü işaret etmek lâzimdır : D. 3,5 , fr. $7,3$.

64) Just, İnst. IIII, 27, s. 
$\left.1^{\circ}\right)$ Negotiorum gestio'nun neticeleri.

Fuzulî vekil (negotiorum gestor) hile ve kusurundan mesuldür; işi sonuna kadar devam ettirmekle, vekâlet sonunda hesap vermekle, vekâletin temin ettiği menfaatleri kanunî ve hukukî usullere uyarak do. minus'a nakletmekle mükelleftir.

Dominus, fuzulî vekilin zaruni masraflannı tazmin, ve, vekâletter: doğan hak ve mükellefiyetleri kabule mecburdur. Ancak bu mükellefiyet fuzulì vekâlet faydalı neticeler sağladığı vakit mevzu bahistir. ${ }^{65}$

$\left.2^{\circ}\right)$ Negotiorum gestio'nun müeyyidesi.

Klâsik devirde dominus, actio civilis'den, fuzulî vekil actio in factum'dan faydalanmakta idi.

Justinianus hukukunda, actio in factum'lar kalkmış olduğundan karşı'ıklı iki hüsnüniyet davası fuzulì vekâletin neticelerini temin ve tayin eder : Actio negotiorum gestorum directa, actio negotiorum gesto. rum contraria. Birincisi dominus, ikincisi negotiorum gestor lehine is. ler. 66

Mandatum'un müeyyidesi olan davalarla bunlar arasındaki fark birincilerinin akitten ikincilerin yapılan iş dolayısı ile doğmuş olmalarıdır.

\section{$\S \mathbf{V}-$ PACTUM'LAR}

I - Pactus ve contractus arasindaki farklar.

Akitler dava i'e müeyyidelenen hukukî bağlar olduğu halde pactum'lar prensip itibariyle exceptio doğuran anlaşmalardır.

Bununla beraber bilhassa pretör pactum'larn, ek pactum'lar ve nihayet Imparatorluk hukuku pacrum'lannın da borç doğuracakları, ve binnetice, dava ile müeyyidelenecekleri kabul edildi.

65) R. Moiner, Manuel, T. II, p : 274, N: 2 .

Dominus'un muameleyi tasvibi mandatum'a benzetilmiş ise de : (Ulp. D. 46,3 , fr. 12,4$)$ bu halde bile actio negotiorum verilmekte olduğu metinlerle mevcuktur : D. 3, 5, fr. 5, 11-13.

Muhakkak olan cihet icazetten sonra dominus'un fuzulî vekâletin fayda. sız olduğundan bahsetmeğe hakkı olmadığıdır.

66) Just, Inst, III, 27, 1 ; D. 3, 5, fr. 3, 7. 
Şu halde bu fasılda bilhassa bu üç tip pactus'u tetkik edeceğiz.

II - Dava ile müeyyidelenen pạctum'lar.

1. Pretör pacrum'lan.

2. Pacta adjecta.

3. Imparator hukuku pactum'lar.

1. Pretör pactum'lan:

Jus civile ile muayyen bir müeyyidesi bulunmayan hukukî bağlantıları müeyyidelemek maksadı ile pretör hile ile yapılmamıs olan anlassmaları exceptio vermek suretiyle muteber saymakta idi. ${ }^{67}$

Bundan başka, pretör karşılıklı nzaya dayanan ve jus civile usulleri haricinde yaplan anlaşmalan da in factum davalar ile müeyyidele. mek suretiyle daha ehemmiyetli bir iş yapmıs oldu : pactum'ların akitler . gibi hüküm ve netice doğurması.

Pretör pactum'larından bu suretle dava ile müeyyidelenmiş olanlan bilhassa șunlardır :

\section{A - Yeminli pactum'lar. ${ }^{68}$}

Her çeşit anlaşmazlığı hal için müracaat olunabilen bu pactum, müddeinin müddeialeyhin borçlu olmadığına dair yemin etmesi halinde takibatłan vazgeçeceğini, veya, müddei yemin ettiği takdirde davalının mevcudiyeti yeminle tevsik edilmiş olan borcu yerine getireceğini konı edinen bir anlaşmadir.

Verilen yemin yerine getirilmez ise pretör ya actio de jurajurando veya exceptio jurisjurandi'yi bahşeder. Exceptio borcu olmadığına dair yemin etmiş olan davalı lehine verilir. Bu exceptio ile pactum'a rağmen davacının açtığı dava reddedilir. Actio de jurejurando alacaklı olduğuna dair yemin etmiş olan davacıya verilir. ${ }^{69}$

$$
\text { B - Recepta. }
$$

Receptum, recipere (teklif etmek, üzerine almak) kelimesinden gelir ve üç çeşit gösterir :

67) Giffard, Précis, 1934, t. II p: 106, N: 1, R. Monier, Manuel, t. II, p: 256, No: 148 .

68) Lenel, Edictum, 1927, p : 149.

69) Pactum'un yerine getirilmemesi, yani yemin teklif eden davalının borcunu ödememesi halinde, yemin eden müddei ekseriya pretörün verdiği bu davayı borcu müeyyideleyen jus civile davasına tercih eder, çünkü ispat külfeti sırf yemin ettiğini beyana inhisar eder. 
a) Receptum arbitrii. 70

Bir anlaşmazlığın havale edildiği hakemi bunu hal ile mükellef kılan bir pretör pactum'udur. Hakem ihtilâfı hal ile mükelleftir ; aksi takdirde para cezasına çarpılır. ${ }^{71}$

b) Receptum nautarum, cauponum ve stabulariorum.

Kaptanlann, hancı ve ahırcılara bırakılan eşyanın bunların kusurlan haricinde zayi olmalan halinde bile mesul tutulacaklarını mümkün kılan pretör pactum'udur. Mamafih, şeyin ziyal mücbir sebebe mebni ise mesuliyet yoktur.

Mesuliyet için şeyi tevdi edenle yukarıda sözü geçen şahıslar arasında bir anlaşma yapılmıs olmasına lüzum yoktur. Teslim fiili receptum un teșekkülü için kâfidir.

c) Receptum argentarii 72

Bir bankerin başkasının borcunu ödemeği üzerine almasından ibaret olan bu receptum ile bankacılar bilhassa müşterilerinin borçlannı ödemeyi tekeffül ediyorlard. Bu mükellefiyet kefilinkinin bir benzeri ise de, receptum argentarii şahsî $\mathbf{v}$ aynî garantinin imtizacından ibaret bir garanti ifade eder ; zira, argentarius (banker) da müşterisinin mutlaka muayyen bir mikdar parası da bulunmalı idi. ${ }^{73}$

Receptum argentarii bilhassa ehemmiyetli ticarì münasebetler arifesinde bulunan müşterilere yapılan aynî ve şahsî krediyi sağlamakta idi. Şu halde, peşinen mevcut bir borca lüzum da yoktu.

$\mathrm{Bu}$ izahattan, alacaklı üçüncü şahsın doğrudan doğruya bankere değil, asıl borçluya, bankerin müşterisine müracaat edeceği neticesi çıkanlır. Müșteri ödeyemeyecek durumda bulunduğu takdirde edayı bankere havale eder ; banker ödemez ise aleyhine actio recepticia açlır. ${ }^{74}$

70) Lenel, Edictum, 1927, p : 131 et $\mathrm{s}$.

71) D. 4,8 , fr. 32,12 .

72) Deloume, Les manieurs d'argent à Rome, 1898, p : 1 et s; Appert, Rev. hist. de droit, 1932, p: 643 et s.

73) Mevdu paranın ödenecek borca tekabül etmesine lüzum yoktu, esasen bu, Receptum argentarii'nin aynı zamanda şahsî kredi mahiyeti göstermesi ile de anlașlin.

74) Bazı müellifler bu davanın in factum bir dava olduğunu tevsik etmektedirler : Lenel, Edictum, 1927, p: 132 et s. 
Justinianus hukukunda bu davaya ve hattâ receptum argentarii tâbirlerine tesadüf olunmaz. ${ }^{75}$

\section{$\mathrm{C}-$ Constitutum.}

Bir şahsın gerek kendisine, gerekse başkasına ait evvelce mevcu! bir borcun edasını şekil ve merasime uymaksızın kabul etmesini konu edinen bir pactum'dur.

Constitutum evvelâ borcunu vadesinde ödememiş veya ödeyememiş olan borçluya muayyen bir müddet, ek bir vade vermek için kullanilyordu: verilen müddetin bitiminde borcu ödemeyen veya bu ek mühleti suiniyetle alan borçlu actio de pecunia constitua'ya maruzdu.

Sonralar, pretör hukuku constitutum'a hemen hemen stipulatio'nun şumulünü tanıdi.

a) Constitutum çeşitleri :

Mevzuuna göre iki tip constitutum varàır :

$\left.1^{\circ}\right)$ Censtitum debiti proprii :

$\mathrm{Bu}$, kendine ait olan bir borcun ifası için istenilen mühletin tespitine yarayan constitumtum'dur.

$2^{\circ}$ ) Constitum debiti alieni. ${ }^{77}$

$\mathrm{Bu}$, bașkasının borcunu eda için girișilen constitutum'dur.

b) Constitutum'un şartları :

$1^{\circ}$ ) C̈deme vadinde bulunan muayyen bir müddet tespit etmelidir. Mamafih, Klâsik devirde müddet tespit edilmeden yapılan constitutum'lar muteberdi. Justinianus hukukunda bu prensip devam etmek!e beraber, ödeme vadinde bulunan müddet tâyin etmemiş olsa bile on günlük mühletten faydalanur.

75) Bu receptum ve müeyyidesi pacta de constitut ile birleștirildi : Collinet, Etudes hist. sur le droit de Justinien, 1912, t. I, p : 270 et s; Receptum argentarii garbî Romada devam ve bankacılıkta büyük tesir icra etti: Huvelin, Cours, II, 1929, p: 113.

76) A. Pilippin, Le pacte de constitut, thèse, 1929 ; Lenel, Das Edictum, 1927 p: 247 et $\mathrm{s}$.

Constitutum, gün tayin etmek mânasına gelen constituere'den gelir.

77) D. 13,5 , fr. 14 , pr. 
$2^{\circ}$ ) Para ve muayyen şeylerin eda ve teslimi için de constitutum muteberdir.

$3^{\circ}$ ) Constitutum evvelce mevcut bir borcun ifası için mümkündür.

c) Constitum'un tatbik sahası :

Sahası çok geniş olan constitutum ancak yeni bir borç yaratmaya kadir değildir.

Constitutum başkasının borcunu da ödemek için yapılabileceğinden kefalet rolünü oynar. Nihayet, constitutum pactum'lan müeyyidesiz borçlan müeyyidelemeye yarar: tabiî borçlar constitutum ile medenî, kanunî borç mahiyetini muhafaza ederler.

\section{Pacta adjecta. ${ }^{78}$}

Akitlerin neticelerini değiştiren veya akit yapıldığı an veya sonra ona eklenen pactum'lardir. ${ }^{79}$

Ek pactum'lar evvelâ borçlunun mükellefiyetini azaltmak maksadı ile yapılan pactum conventum'larla başlar. Sonralan, bilhassa İmparatorluk devrinde borçlunun mükellefiyetini çoğaltan pactum'lar da belirdi. Birinci pactum'lara ad minuendam obligationem, ikincilere pactum ad augendam obligationem denir.

\section{A - Pactum ad minuendam :}

Akdin borçluya yüklediği mükellefiyetleri indirmek için yapılan bu ek anlaşma bilhassa kesin hukuk mukavelelerinin sert, adalet ve hüsnüniyetle uyuşmasına imkân olmayan hükümlerini borçlu lehine değiştirmek maksadı ile yapiliyordu. ${ }^{80}$

\section{B - Pactum ad augendam obligationem :}

Borçlunun mükellefiyetini çoğaltmak için yaprlan bu ek anlaşm:lardan alacaklı faydalanır.

78) Viard, Les pactes adjoints aux contrats en droit romain classique, 1928; Boyer, Rev. hist. de droit, 1931, p: 141 et s.

79) Akitle birlikte yapllan pactum lara in continendi, diğerlerine, yani sonradan akde eklenenlere, ex intervallo pactum'lar denir.

Ek pactum'lar menşeini borçlunun mükellefiyetini azaltmak için ileri sürdüğü exceptio'larda aramak lâzımdır : Koschaker, Festscher. f. Hanausek, $\mathrm{p}: 155$ et $\mathrm{s}$.

80) Hüsnüniyet mukavelelerinde ek mukaveleye lüzum olamazdı, çünkü bu mukavelelerde exceptio daima ileri sürülebilirdi. 
Roma daha ziyade akitle birlikte yapılmış olan pactum'lan işledi, ve bu pactum'larm hüküm ve neticelerini mukavelenin hususî şartlaiı mahiyetinde mütalâa etti. ${ }^{81} \quad$ -

Justinianus hukukunda mükelefiyeti arłıracak olan pactum hüküı?lerinin asıl akdin mahiyeti ile uygun düşmesi lâzımdı: Mutuum da faizi artıracak olan pactum in continendi'ler muteber değildi.

3. Kanunî pactum'lar (Pacta legitima) :

Imparatoriuk devrinde kat'î hukuk davaları ile müeyyidelenmiş olan pactum'lar olup üç çeşit gösterirler: Compromissum, çehiz tesisine dair pactum, hibe anlaşmalan.

\section{A-Compromissum (Tahkim) $:^{82}$}

Compromissum bir anlaşmazliğın iki şahıs tarafından hakem marifeti ile halledilmesine rza göstermeleridir.

Klâsik devirde her iki taraf hakemin vereceği hükme riayet edeceklrini peşinen garantilemek üzere stipulatio ile muayyen bir poena'yı vadederlerdi. Hüküm temyiz olunamaz.

Justinianus hukukunda tahkim, taraflarm ve hakemin yemini ile takviye olunmuș ise mecburî idi. Mamafih, 82 nci novellae bu hususda şu kaideyi koydu: taraflar hükme riayet edeceklerini yazılı olarak beyan etmişler veya hükümden sonra 10 gün içinde itirazda bulunmamışlarsa tahkimin neticesi kat'îdir.

Görülüyor ki, Justinianus hukukunda, Klâsik devir hilâfına olarak, tahkim için stipulatio mecburî değildir.

\section{$B$ - Çehiz tesisi pactum'u ::}

Çehiz tesisi çeşitli hukukî yollarla mümkündü: dictio dotis, stipulatio, acceptilatio ilh. ;

İmparatorluk devri mücerret çehiz tesisi vadini de pactum olarak kabul etmiş olmakla çehiz tesisini kolaylaştırmış bulunmaktadır. Her türlü şekilden azâde olan bu vaade muhatap bulunduğunu ispat eden

81) Georgesco, Leges privatae, 1932, p: 212, 219.

82) Roussier, Du compromis'sine poena en droit romain classique : (Rev. hist. de droit, 1939, p: 167 et $\mathrm{s}$. 
koca, condistio ex lege'yi, yani bütün kanunî pactum'larm müeyyidesi olan davayı açmakla mev'ut cihazı temin eder.

Cihaz tesisine dair verilen mücerret sözü mecburî hale getiren bu söze kanuniyet veren Théodosianus ve valentinien'dir (428).

C - Hibe için pactum'lar :

a) Hibenin (Donatio) tarihçesi ::

$\left.1^{\circ}\right)$ Eski hukukda hibe :

Aşağı İmparatorluk devrine kadar hibe için hususî bir şekil olmadığı gibi, mücerret bir beyan da kâfi değildi : Hibe șekle bağlı akitlere uyularak yapılmakta idi. Bu hususta kaide şu idi: bir şahsın mamelekin. de eksilme, diğerininkinde fazlalık yaratan her muamele hibe hükmünde idi, şu tek şartla ki vahib hibe yapmak niyeti (animus donendi) ile hareket etmiş olsun.

\section{$2^{\circ}$ ) Klâsik devirde hibe :}

Klâsik devirde donatio, mancipatio veya Traditio ile yapılmakta idi. $\mathrm{Bu}$ suretle hibe edilen şeyin mülkiyet ve zilyedliği naklediliyordu. Mancipatio ve traditio'dan evvel seyin devri mecburiyetini doğuran stipulatio yapılmakta idi. Bundan başka, ibra (acceptilatio) da donatio'yu tesise kâfi gelebiliyordu.

$3^{\circ}$ ) Imparatorluk devrinde hibe :

İmparatorluk hukukunda donatio gerek şekli ve gerekse neticeleri bakımından incelendi: M. E. 3 ncü asır sonlanında hibeye karşı teşrî̀ ve örfî aksülâméller belirdi. M. E. 204 de çıkan lex cincia hibeyi, hibe yapılabilecek ve yapılamıacak halleri göstermek suretiyle tahdit etti. ${ }^{83}$

Klâsik devirde bu kanun pretör vasıtası ile tatbik olunmakta idi : kanunî hâd aşlarak yapilan hibelerin iptali için pretör exceptio legis cinciae'yu bahşediyordu. ${ }^{84}$

Ehemmiyetli olan cihet vahibin hibe mevzuunun mülkiyetini hibe edilen şahsa devretmiş olmasından sonra exceptio'dan faydalanamıyacağıdır. ${ }^{85}$

83) Avukatlar dava takibi için kanunî haddi așan ücret veya hediye kabul edemezler : Kanunî hâd akraba ve karı koca için mevzu bahis değildi. Teferruat : Appleton, Rev. hist. de droit, 1931, p: 424 et s.

84) Ferrari, Studi Riccobono, I, p: 473 et s.

85) Mamafih, menkul şeylerde hüküm aynı değildi : vahip altı ay içinde interdictum utrubi ile șeyi geri alabilir. 
Vahibin ölümü exceptio legis cinciae'nin mirascilar tarafından kułlanılmasına mahal vermez.

b) Karı koca arasındaki hibeler :86

(Donatio inter virum et uxorem.)

Caracalla'nın teklifi ile çıan bir Senatus - consultus (M. S. 206) bu sert hükmü tadil etti: lehine hibe yapilan kan veya koca evlilik bağı devam ederken hibe yapanın ölmüş olması ve ölüm anına kadar hibeden vaz geçmemesi şartı ile hibe edilen şeyi muhafaza eder. Justinianus da bu kaideyi lehine hibe yapılan taraf menfaatine daha çck mülâyemetle tatbik etti. Fakat, Imparator, lehine hibe yapılanın hibe yapandan evvel ö:mesi halinde hibeyi muteber saymaz. ${ }^{87}$

İmparatorluk devri hibelerin hususî fesih sebepleri üzerinde de durdu: azâdlıya yapılan hibe azâdlının nakadirşinaslığı halinde fesholunur. $\mathrm{Bu}$ kaide Justinianus tarafindan bütün hibe hallerine tatbik olundu. ${ }^{88}$

Donatio Justinianus Pactum ile yapllabilir: mücerret hibe vadi muteberdir ve kanunla müeyyidelenir. Bu suretle hibe yapmak için başka bir akit tipine müracaata lüzum yoktur. ${ }^{89}$ Animus donendi'nin vücudu kâfidir, şu şartla ki lehine hibe yapılan şahıs da hibeyi kabul için irade beyanında bulunmuş olsun.

\section{§ VI. ÂKITLERIN NETICELERI}

(Borçların hükmü) :

$\mathrm{Bu}$ fasılda akitlerin icrası, icra edilmemesi ve temerrüd bahislerini tetkik edeceğiz.

I - Akitlerin icrası :90

Roma hukukunda borçlann sukutu, akitlerin yerine getirilmesi ilk defa mutuum'da ödeme (eda) ile mevzubahis oldu. ${ }^{91}$

86) Dumont, Led donations entre époux en droit romain, 1928.

87) Constantin'den itiłaren hibelerin tescili lâzımdı. Tescil İmparatorluk memurları tarafından yapılır; Tescile tâbi hibeler, Théodos zamanındz 200, Justinianus devrinde 500 altin sikke kiymetinde olanlardır.

88) R. Monier, Manuel, t. II, p: 267, No: 153.

89) Just, Inst. II, 7, 2.

90) Ed. Cuq, Mannuel, 1928, p: 613.

91) Borçların sukutu ile ifası arasında fark olduğu aşikârdır : Ifa bizzat alacaklıyı tatmin eder, sukut sebepleri ise bazan borçluyu (acceptilatio ve 
1. Akitlerin icrasının (borçlann ifasının) tarifi ve bu husustaki genel prensipler.

Ifa, akdin mevzuuna göre bir şeyin edası, yapılma veya yapılmaması şekillerinde tecelli edebilir.

2. Akitlerin icrasının esaslı şartlan.

Borcun ifası borçluyu borçtan kurtarabilmek için şu şartlara uygun düşmelidir :

$1^{\circ}$ ) Prensip itibariyle ifa herkes tarafindan yapilabilir.92 Ancak borçlunun şahsı ile ilgili bulunan borçlar bizzat borçlu tarafından yerine getirilir.

Üçüncü şahıs tarafindan yapılan ödemenin muteber olabilmesi için borç ödeyenin gayrin borcunu ödediğini bilmesi lâzımdır, aksi takdirde borçlu olunmayan şeyin edası mevžubahistir.

$2^{\circ}$ ) Ifa ehil bir kimseye karşı yapılmalıdır. Eda bizzat alacaklıya veya vekiline yapilır. ${ }^{93}$ dir. ${ }^{94}$

$3^{\circ}$ ) Ödeme borç mevzuuna tamamiyle uygun olarak yapilmaly-

Borçlu, prensip itibariyle borcun tamamını ödemekle mükelleftir. ${ }^{9:}$ Kaynağı çeşitli bulunan müteaddit borçla mükellef borçlu kendisine en uygun geleni ödeyebilir. ${ }^{96}$

Imparatorluk devrinde de prensip mukavele edilmiş olan şeyin edasıdır. Mamafih, alacaklı razı olursa, datio in solutum, yani mukavele edilmiş şeyden başka bir şey vermek suretiyle eda muteberdir. Proculienlerce açlacak dạvaya karşı bir exceptio imkânı veren datio in solutum

zaman aşımında olduğu gibi) tatmin eder, bazı hallerde de her iki taraf 1 da tatmin etmez.

92) Hattâ borçlunun kim olduğu bilinmeden ve onun arzusu hilâfına bile başkası tarafından eda muteberdir : D. 3, 5, fr. 38 .

93) Adstipulator (fer'i alacaklı), adjectus solutionis gratia (edaya vekil edilen şahıs) a da yapılan ifa muteberdir : Just, İnst. III, 19, 4.;

94) C. 18,4 , fr. 21.

95) 'Mamafih, Justinianus hukukunda Majistra alacaklıyı kısmî edaya mecbụr tutabilir : D. 12, 1, fr. 21; Ancak bu hal hükümle vaki edalarda mevzubahis değildir.

96) C. VIII, 42 , Cost. 1. 
Sabinienlerce borcun sukutunu temin eder. İmparatorluk hukuku Sabinienlerin görüs tarzını tatbik etti. ${ }^{97}$

Datio in solutum'un muteber olabilmesi için alacaklının devredilen şeyin maliki kılınması lâzımdır. Bu suretle datio in solutum borçlu ile alacaklı arasındaki emptio venditio'ya benzetilmiştir.

Justinianus hukukunda da bu esastan hareket edilerek alacakliya şeyin gizli ayıplarndan ve şeye karşı istihkakdan ötürü tazminat davasindan faydalanması kabul edildi. ${ }^{98}$

\section{Edanin ispatı :}

Imparatorluk devrine kadar kıymeti ne olursa olsun ödeme her vasita ile ispat olunabiliyordu. İmparatorluk devrinden itibaren alacakłı tarafindan tanzim edilen makbuz edayı teyit eder. ${ }^{99}$

II - Akitlerin icra edilmemesi : 100

Akitler, bilhassa borçlunun şahsı ile ilgili bulunanlar ve nev'î belirtilmiş olan borçları mevzu edinenler, mücbir sebep ve umulmadık hailerden ötürü icra imkânsızlığı ile borçlu tarafindan hiç bir mes'uliyete maruz kalınmaksızın fesholunabilirler.

Ehemmiyetli olan nokta bu iki sebebin ölçülebilen, tartılabilen şeyleri mevzu edinen borç!arı ortadan kaldıamıyacağıdır. Bu iibarladır ki, ceza mahiyetindeki borçlar bu iki sebeple dahi ortadan kalkmazlar. Zira cezaî borç daima mislî şeylerden olan muayyen bir miktar paranın edasından ibarettir.

Borçlarn ifa edilmemesi borçlunun hile ve kusurundan da ileri gelebilir.

Şu halde bu paragrafa sirası ile umulmadik hal, mücbir sebep ve borçlunun fiil ve kusurundan ötürü âdemi ifa ve neticelerini tetkik edeceğiz.

1. Causus minores (Umulmayan haller) :101

97) C. VIII, 42; Cost. 17, A, 293; Steiner, Datio in solutum, Zurich, 1914.

98) D. 13, 7, fr. 24, pr.; Girard, Manuel, p: 733, N: 4.

99) R. Monier, Manuel, 1944, t. II, p: $288 \mathrm{n}: 3$.

100) Arangio-Ruiz Responsabilità contrattuale, 2 ème éd. 1934, p: 287. Luzatto, Caso fortuito e forza maggiore, t. I, La responsabilità per custodie, Milano, p: 285 et $\mathbf{s}$.

101) Just, Inst, III, 23, 3. 
Akdin mevzuunda vaki umulmadik hallerdir ki mukavelenen feshini icap ettirir, ve borçlu mes'ul tutulmaz. Bu sebepler arasında satılan köle veya hayvanın ölmesi ve çalınmasını anmak lâzımdır. Mamafih, bu hallere borçlunun kusuru sebebiyet vermemiş olmalıdır. ${ }^{102}$

Aksine mukavele olmadan dahi Custodi ${ }^{103}$, yani muhafaza, ihtimam nazariyesi mucibince de mes'ul tutulabilir: kölenin zincirli olarak devredilmesi şart koşulmuş idi ise ve teslimden evvel kaçmışa custodia nazariyesince satıcı mes'uldür. ${ }^{104}$

Justinianus hukukunda custos ${ }^{105}$ yanında satıcınm da ihtimam göstermiş olması lâzımdır. ${ }^{106}$

Klâsik devir sonunda custodia aşağı yukarı diligentia ile karıştırıld. ${ }^{107}$

2. Causus majores (Mücbir sebep) :

Mücbir sebep (vis major) önüne geçilemeyen bütün hâdisatı ifade eder: yer sarsmtı $\mathrm{S}_{\mathbf{I}}$ sel, anî ve büyük yangın mücbir sebeplerdendir. ${ }^{108}$ $\mathrm{Bu}$ hallerde borçlu borcundan kurtulmuş olur. Ancak bu sebeplere borçlunun kusuru (culpa) iştirâk etmemiş olmalıdır.

\section{Borçun borçlunun fiili yüzünden ifa edilememesi :}

$\mathrm{Bu}$ üçüncü halde borçlunun mes'uliyetini bazı ayırtlara göre tetkik etmek zarurìdir.

A - Teslimi icap eden borçlarda şeyi ziyaa uğratan müspet her fiilinden ötürü borçlu mes'uldür. Fakat ifayı imkânsız kılan içtinabî hareketinden dolayı jus civile'ce mes'ul değildir. Meselâ satılan hayvan ,hastalığında ihtimam görmez ve ölürse, mes'uliyet yoktur. Mamafih, stipulatio da clausula doli, hileden mütevellit exceptio kaydı varsa borcun ifasinı imkânsız hale koyan içtinabî hareketler de mes'uliyeti muciptir.

102) Ariyet alanın ariyet mevzuunu akitteki gayeden baska gaye ile kullanarak zayi etmesi veya hasara uğraması, veya satıcının akdin inikadından sonra satılan köle veya hayvanı teslim anına kadar normal üstündeki isslerde çalıştırması, iaşesini kesmesi gibi hallerde borçlu mes'uldür: D. 47, 5 , fr. 1,4 .

103) J. B. Paris, La responsabilité de la costudia, thèse, 1926.

104) D. 13,6 , fr. $5,6,13$.

105) Satıcı custos, yani satılan şeyin muhafazasına memur şahıs tâyin etmis ise mes'ul değildir: D. 19, 2, fr. 18, pr.

106) Diligentia in custodia: D. $13,6, \mathrm{fr} .18$, pr.

107) D. 39,2 , fr. 18 , pr.

108) D., 19, 2, 15, 2. 
M. S. 3 üncü asrnn başlarına kadar ifayı imkânsızlaştırma kasdi ile hareket edilip edilmediği de göz önünde tutulmazdı. Bu devirden itibaren borçlu ancak ifa imkânsızlığı kasdi ile hareket etmiş ise mes'uldür; yani bu takdirde ifa imkânsızlığı onu borçtan kurtaramaz.

B - Hüsnüniyet davalan ve in factum davalarla müeyyidelenmiş borçlann ifa edilmemesi halinde mes'uliyet.

Klâsik devirde inkişaf eden bu mes'uliyetin tarihçe ve inkişafı hile ve kusur (culpa) nazariyesinin tarihçe ve inkişafı ile yakından ilgilidir.

a) Dolus (Hile) :

Borcun gerek tamamen gerek kısmen borçlunun müspet veya içt:nabî hilesi ile ifa imkânsızlığına maruz bırakılması mes'uliyeti muciptir. Klâsik devir hukuku borçluyu hilesinden ötürü mes'ul kılacak muameleleri saymıștır. Depositum'u müeyyideleyen in factum davaların formüllerinde bu husus sarihtir. Hüsnüniyet davalannda ise formula'nın exceptio kısmında yazılmamıs olsa bile dolus her zaman borçlunun mbes'uliyetini temin için dermeyan olunur. ${ }^{109}$

\section{$B-$ Culpa (Kusur) :}

$\left.1^{\circ}\right)$ Cezaî ve akdi kusur arasındaki fark :

Culpadan ö!ürü akdi mes'uliyeti gözden geçirmeden evvel akdi ve cezaî culpanın ayırt edici vasıflarını belirtmek faydalıdır. Lex Aquilia, Culpa Levissima (En hafif kusur) yı da cezaî mes'uliyetde esas tutar.r. Akdi mes'uliyet ise, şeyin kısmen veya tamamen kaybedilmesi veya hasara uğratılmasına sebep olan kusur nazara alınır.

Modern haksız fiil nazariyesi Culpa Levissima'yı da ihtiva eder.

$2^{\circ}$ ) Akdi kusur (Culpa) :

Akdi kusur nazariyesi Fides ve Diligentia ile başlar. ${ }^{110}$

Klâsik devir hukukçulan borç̧lunun ifayı imkânsızlaştınıcı müsbé ve menfî her hareketini Culpaya dahil ederler ancak bunlar Culpa nazäriyesinin sübjektif unsuru üzerinde durmamışlardır.

c) Justinianus hukukunda Culpa :

Klâsik Culpa nazariyesindeki bu boşluk Bizans hukukunda dereceleri kabul edilmiş olmakla aşağı yukan doldurulmuş oldu.

109) R. Monier, Manuel, 1944, t. II, p: 303, N: 1.

110) Gaius, inst, I, 200. 
Bizans hukuku akdi mes'uliyete meydan veren dört tip Culpa kabul eder.

$1^{\circ}$ ) Culpa lata (Ağır Kusur) $:^{111}$

Justinianus hukukundan evvelki İmparatorluk devri hukukçulan ağır kusuru zarar kasdı olmaksızın yapılan hileye benzetmișlerdir. Yine aynı devirde herkesin kestirebileceği tehlikelerin önüne geçmemek ve en ehemmiyetli ve zarurî olduğu aşikâr tedbirleri almamış olmak da Culpa lata sayllyordu. ${ }^{112}$

Bu sonuncu hal, yani en az müteyakkız olan bir kimsenin bile ihmal etmiyeceği hareketlerde bulunmak Justinianus hukukunda Culpa lataya dahildir. ${ }^{113}$

$2^{\circ}$ ) Culpa Levis in abstracto :

$\mathrm{Bu}$ müteyakkız bir adamın (Bonus vir), müdebbir bir paterin ișlemiyeceği kusurdur. ${ }^{114}$

Justinianus hukukunda hüsnüniyet mukavelelerinde fazlasile tatbik olunan bu kusur rehinli alacaklyya da tatbik olunmakta idi. ${ }^{115}$

$3^{\circ}$ ) Culpa levis in concreto :

Kendi işlerinde gösterilmemesine imkân olmayan ihmali ifade eden kusurun bir derecesidir.

Koca çєhiz, vasi vesayete tabi kimselerin malları üzerinde Socius şirket mallannda kendi mallan imiş gibi hareket etmeli idiler. Aksi takdirde, Culpa levis'in concreto işlemiş olưrlard. ${ }^{116}$

Zamanımız hukukunda akdi mes'uliyet en ufi: kusur halinde dahi mevzuu bahisdir. Mamafih, modern akdi mes'uliyetin esasın Cúlpa levis in abstracto'daki kaide teşkil eder. ${ }^{117}$

Akidlerin âdemi icrası (Borcun ifa edilmemesi) nin müeyyidesi :

A - Tarihçe :

Kanunun alacaklıya hükme lüzum kalmaksızın borçlunun şahsı-

111) R; Monier, manual, 1944, t. II, $\mathrm{P} / 307, \mathrm{n}: 4$

112) Ulp, Regul, I, 1; Paul, Sent. 1, 2.

1133) Giffard, Précis, t. II, 1934, p: 275, N: 1.

114) D. 9,2 , fr. 31.

115) Just, Inst, III, 14, 4.

116) D. 17,2 , fr. $72 ; \mathrm{D} ; 27,3$, fr. 1 . pr.

117) Henri etL.Mazeaud, traité de laresposabilité civile, t; I, no: $36,50$. 
na el koymasına müsaade ettiği haller müstesna akdin icra edilmemesinden mutazarrır alacaklı borçlunun mes'uliyeti için hüküm istihsaline mecburdur.

Klâsik devirde mahkûmiyet prensip itibariyle muayyen bir mikdar paraya müncer olur. Hâkim borçluyu borcu yerine getirmeğe mahkûmı edemez. ${ }^{118}$

Alacaklı aleyhine mahzurlar doğuracak olan bu kaide formüllü da. va usulile hafifletildi. Litis Contestatio'dan sonra borçlunun yapacağı eda muteber sayıldı; bazı davalarda hâkim evvelâ borçluyu akdi icraya davet etmek imkânını da buldu.

Hüküm asıl borçtan daha müessir bir borç doğurur: mahkûmiyeł mevzuunu yerine getirmek. ${ }^{119}$ Mahkûm akdî borçlu, suçlu muamelesi görür: mahkûmiyet bahşedilen müddet içinde yerine getirilmez, meblây̆ ödenmezse alacaklı manus injectio'ya müracaat eder. Bundan başka, pretör borçlunun emvaline haciz de koyabilir.

Fevkalâde yargılama usulünde prensip akitlerin mevzuunun yerine getirilmesidir. Binaenaeyh, bu devirde modern hukuka yaklaşılmıs bulunulmaktadır. ${ }^{120}$ Bununla beraber Justinianus Klâsik devir prensiplerine de yer vermiştir. ${ }^{121}$

\section{$B-$ Tazminat :}

Roma hukuk tarihinde akdin icra edilmemesinden doğan zarar ziyanın tazmin ve takdiri iki bakımdan incelenmelidir: hâkim ve taraflarca tazminatın takdiri.

d) Tazminatın hâkim tarafından takdiri.

Formülünde mahkûmiỵ̂t miktan derpiş edilmiş olan davalarda (condictio certa pecuniae) hâkim bu miktarda mahkûm edecektir.

Diğer hallerde hâkim, tazminatın şumulünü takdirde serbesttir. Bazı hallerde, müdeinin yemini üzerine de takdir mevzubahistir. Hâkim takdir hakkını litis contestatio'yu göz önünde tutarak kullanır.

Klâsik devirde hâkim akit icra edilse idi alacaklının edineceği kasancı da göz önünde tutarak hükmeder.

118) Gaius, inst, IV, 48. 
Justinianus hukukunda, hâkimin ancak doğrudan doğruya vaki zararlara itibar ederek takdir hakkı kullanacağı ve beyide tazminat miktannın mebiin itibarî kıymetinin iki mislini aşamıacağı kabúl edildi.

Stipulatio'daki aksine sarahat müstesna, tazminat semereleri ve faizleri de ihtiva eder.

Justinianus hukukunda faiz davanın başladığı andan işler. ${ }^{122}$

Mamafih, hüsnüniyet davalannda faiz temerrüd anından itibaren işler, ve, semereler ekseriye akdin inikadı günü nazara alınarak hesaplanır. Beyide de hüküm böyledir. ${ }^{123}$ Faiz ve semereler formülde mevzubahis edilmediğinden hâkimin takdir hakkı bu hususta tamdır.

b) Zarar ve ziyanın taraflarca tesbiti.

Stipulatio poenae (Cezaî şart) :

Hâkimin muhtemel yanlış takdirinin önüne geçilmesi ve bilhassa ifanın peşinen garantilenmesi mülâhazası ile taraflar akdin inikadı ânında akdin âdemi icrası halinde verilecek tazminat miktarını tâyin edebilirler. Stipulatio poenae'yi yapacak olan taraf borçludur.

Cezaî şart iki tip stipulatio ile koşulabilir: Şarta bağlı stipulatio, ki bunda borç ifa edilmediği zaman muayyen bir miktar paranın alacakìya edası vaad olunur. Bu stipulatio hem asıl borcu hem de cezaî șartı ihtiva eder: şu köleyi vermez isen 100 sesteres verir misin?... gibi.

Ikinci tip stipulatio da ardı ardına iki stipulatio mevcuttur: şu köie. yi vermeyi vadediyor musun? Eğer vermez isen 100 sestres verir misin? gibi.

Eski tipi ifade eden birinci stipulatio'da borç ödenmediği takdirde cezaî şart ödenecektir, öyle ki, borç kısmen ödenmiş olsa bil cezaî şart tamamen eda olunmalıdır. ${ }^{124}$ Diğer cihetten, borçlu, şeyin mücbir sebep ve umulmadık hallerle teslim edilememesi halinde bile cezaî şar$\mathfrak{t}_{1}$ edaya mecburdur. ${ }^{125}$

119) Gaius, Inst. IV. 180.

120) Just, Inst, IV, 6, 31

121) Just, Inst, IV, 6, 32.

122) D. 22,1 , fr. 35.

123) R. Monier, Manuel, t. II, 1944, p: 314.'

124) D. 45,1 , fr. $85,6$.

125) Çünkü asıl borç cezaî şarttan ibarettir: Paul, D. 44, 7, fr. 44, 5. 
Ikinci tip stipulatio da hem asıl borcun hem de cezaî şartın edast ayn ayrı şart koşulmuş bulunmaktadır. Cezâ̂ şartı ihtiva eden stipulatio nun rolü asıl borcun ifa edilmemesi halinde zarar ziyanı tespit etmekdir. Binaenaleyh, bu cezaî şart tam mânası ile cezaî mahiyet gösîermez. Binnetice asıl borcun $\mathrm{k}_{1} \mathrm{Sm}$ en edası halinde de cezaî şart lâzımgelir. ${ }^{126}$

\section{Fraus creditorum. ${ }^{127}$}

$\mathrm{Bu}$ paragrafda borç ödemekten âciz durumda bulunan borçlunun ve alacaklıyı zarara sokmak niyeti ile mamelekinde yapmış olduğu azaltıcı tasarrufların hüküm ve neticelerinden bahsedeceğiz.

\section{A - Fraus'un tarihçesi :}

Bu hususla ilgili D́igesta metinlerinin kısmen değiştirilmiş olması ve ilâvelere uğramış bulunması, ve hele Justinianus hukukçularının Fraus'u önleyen Pretör edictum'ları ile Bizans nazariyesini birbirine karıştırmış olmaları, Fraus'un tarihçesini kat'îyetle belirtmeyi hayli güçleştirir.

a) Klâsik devirde Fraus.

Müelliflerin ekserisi ${ }^{128}$ restitutio in integrum yanında pretörün fruas'u men edici edictum'lar bahşetmekte olduğu kanaatindedirler. Fraus'a maruz alacaklılar ceza davasına müracaat edebiliyorlrad.

\section{b) Pretör hukukunda fraus.}

Ciceron devrinden itibaren ${ }^{129}$ pretör, alacaklılan himaye etmek üzere vendïio bonorum müessesesini işletmektedir: curator bonorum pretörden restitutio in integrum talep etmeğe haklıdır: pretör fraudator (borç ödemekten âciz ve hileli tasarruflarda bulunan borçlunun sui niyetli üçüncü şahıslarla yaptığı mamelekinin passifini artıncı muamelelexi hükümsüz addediyordu. Pretör, aynı zamanda, bonorum emptor'u da, hileli tasarruflarda bulunmuş oaln üçüncü şahıslann takip ihtimallerine karşı exceptio fraudis'i bahşetmek suretiyle, himaye ediyordu. ${ }^{130}$

126) Fraus kelimesi ekseriya hileli hareketler için kullanılır; akitlerin icra edilmemesi, borçların âdemi ifası bahsindeki mânası tamamiyle tekniktir: borçlunun alacakları aleyhine giriştiği her türlü muamele ve bilhassa tasarrufat, mahkûm borçlunun emvali üzerindeki alacaklıları zarara sokucu her türlü hareketi fraus'u ifade eder.

127) Lenel, Das edictum, 1927, p: 435 et $\mathrm{s}$.

128) Ed. Cuq, Manuel, 1928, p: 587; Giffard, Précis, t. II, N: 380; Girard, Manuel, p: 455 et s; R. Monier, t. II, p: 319.

129) Girard, Manuel, p: 457, n: 3; Lenel, Edictum, 1927, p: 435, N: 8.

130) D. 12,2 , fr. 9, 5. 
Pretörün ehemmiyetli işlerinden biri de venditio boşorumdan kismen faydalanmış olan alacaklılara fraudator'un üçüncü şahıslarla yapmış olduğu ve emptio venditio'ya kadar gizli kalmış bulunan muamelele。 rin feshini temin etmek için fraus dolayısı ile interdictum bahşetmesi idi. ${ }^{131}$

Interdictum fraudatorium bilhassa fraudator'un iradesi ile eksilen (derelictio da olduğu gibi) mamelekin eski hale getirilmesini sağlar. ${ }^{132}$

Interdictum fraudatorium fraus'dan faydalanan kötü niyetli üçüncü şahıslara karşı verilmekte idi. Mamafih, hüsnüniyetli üçüncü şahıslar da in factum davalar ile takip olunabiliyorlard.

Interdictum frałidatorium, restitutio in integrum hilâfina olarak, bütün semerelerin iadesini sağlamaz: bu interdictum ile şeyin devri anındaki semerelerle, interdictumun verildiği andan sonraki semereler temin edilir.

\section{c) Justinianus hukukunda Fraus Creditorum. ${ }^{133}$}

(Actio Paulienne). ${ }^{134}$

Bizans hukuku, Restitutio in inteğrum ve interdictum fraudatorium'u kaldırdı ve actio paulienne adile infactum bir davayı fraus'in mieyyidesi kıld.

Justianus hukukunda Venditio Bonorum yerine Distractio bonurum tatbik sahasındadır. Distractio bonorum ile tamamile tatmin edilmemiș olan her alacaklı Fraus yolile yapılmış olan tasarrufatın feshi için iptal davasından faydalanır.

\section{B - Iptal davast ve şartlart :}

a) Bonormu şartlan :

İptal davasından faydalanabilmek için şu şartlar lâzımdır :

$\left.1^{\circ}\right)$ Fraus'l Azad ibtale mütehammil değildir azadlamaların ibtali için hususî kanuı lâzımdır. ${ }^{135}$

131) D. 42,8 , frfr; $10,18$.

132) Halbuki, Restitutio in integrum hukukî bir muamele dolayısı ile verilmekte idi.

133) Just, Inst. IV, 6, 1; D. 42, 8, fr. 6, 8.

134) Davanın menşei için: P. Collinet, Origine Byzantine $d u$ nom $d e$ la Paulienne: Nouv. Rev. hist. 1919, p: 187 et s. 
$2^{\circ}$ ) Borçlu, mamelekini azaltıcı hukuki bir muamele yapmış olmalıdır.

Borçlunun devrettiği şey bedelinden az bir semenle devredilmiş ise farus var sayllır.

İşaret olunsun ki, actio Paulienne mameleki zenginleştirici muamelelerin ihmal edilmiş, ve meselâ hibenin reddedilmiş olması halinde, iş. lemez.

Modern hukukta da prensip ayıdır, fakat Romanın hilâfına olarak mirasın reddi caiz değildir.

Actio Paulienne, interdictum fraudatorium'dan farklı olarak, muvazaalı, fraus'a müstenit aynî garantilexi de iptal eder.

$3^{\circ}$ ) Borçlunun borç ödemekten âciz bulunduğu, ve ekseriya em. valinin distractio bonorum ile satılmakta bulunduğu veya satılmış olduğu ispat olunmalıdır.

$\left.4^{\circ}\right)$ Consilium fraudis'in, yani iltizam edici muameleye girişen borçlunun alacaklıları zarara uğratmak maksadı ile hareket etmiş olması lâzımdır.

c) İptal davasının mahiyet ve neticeleri :

İptal davasının mahiyeti :

$\left.1^{\circ}\right)$ Iptal davası hâkime takdir hakkı veren davalardandır. Binaenaleyh, fraus'lu muamelede bulunan üçüncü şahıs şeyin mülkiyetini devirden çekindiği zaman actio Paulienne veriliyordu. Dava fraudator'a karşı açılabileceği gibi kötü niyetli üçüncü şahsa karşı da açlabilir.

$\left.2^{\circ}\right)$ Actio Paulienne'nin neticeleri :

Îlk netice fraus ile yapılan akit veya tasarrufun yapılmamıs addedi!mesi ile ifade olunur. Dava; isterse üçüncü şahıs mamelekini artırmamış bulunsun, alacaklının uğradığı bütün zarar ve ziyanın tazminini sağlar.

Justinianus hukuku, hakh olarak, fraudator ve üçüncü şahsın mirasçılannı da bu dava ile takibini kabul eder. Üçüncü şahsın mirasçılan zenginledikleri nispette, fraudator'un mirasçlan da hile ile mameleklerini fakirleştirdikleri nispet dahilinde mes'uldürler. ${ }^{136}$

135) Solazzi, Revoca, 1934, p: 96 et s.

136) Solazzi, Revoca, $1934, \mathrm{p}$ : 181 et $\mathrm{s}$. 


\section{III — Temerrüd (Mora) $::^{137}$}

1. Giriș.

Borcun ifa edilmemesi ile mora arasındaki fark bârizdir: âdemi ifa akdin nihaî surette yerine getirilmemesi, temerrüd ise akdin muvakkaten icra olunmamasından ibarettir. Diğer cihetten, akdin âdemi icrasının hükümleri sırf borçlu aleyhine neticeler vücuda getirir; temerrüd ise, bazan alacaklının kusuru ile de vukubulacağmdan, hüküm ve neticelerini alacaklı aleyhine de doğurabilir. Bu husus Mora creditoris tetkik olunurken görülecektir.

\section{Temerrüdün çeşitleri :}

Temerrüd, muaccel borcun vaktinde yerine getirilmemesidir; ya borçlunun veya alacaklının fïlinden ileri gelebilir; birinci halde borçlunun temerrüdü, ikinci halde alacaklının temerrüdü mevzubahistir.

Hüküm ve neticelerinde değişiklik olan bu iki temerrüdün ayn ayn tetkiki zarurîdir. .

\section{A - Borçlunun temerrüdü (Mora debitoris) :}

a) Borçlunun temerrüdü şartlan :

Klâsik devirde muaccel borcu zamaninda, yani vadenin bitimi veya talikî şartın tahakkuku anında ifa etmeyen borçlu mütemerrid sayılırdı. Muacceliyet anında, hiç değilse gününde, akdin borçlu tarafından icra edilmemiş olması temerrüd için kâfi bir şarttı. ${ }^{138}$

$\left.1^{\circ}\right)$ Interpellatio (lhtar) :

Justinianus hukuku sırf muacceliyetin borçluyu mütemerrid vaziyete sokamıyacağı kaidesini koydu: alacaklı muaccel borcun borçlusına ifayı bildirir ihbarda bulunmalıdır. ${ }^{139}$

Interpellatio, borç ihtilâflı olduğu hallerde borçluyu temerrüde sevk

137) Guarneri, Contributi alla dottrina della mora (Annali. Palermo, 1924, p: 161 et s. ; Huvelin, Furtum, 1915, p: 363.

138) Girard, Manuel, p: 689, n: 3.

139) Borcun mahiyeti muacceliyet anında itayı mümkün kılmaz veya borçlu pactum ile bir mühletten faydalanlyorsa interpellatio ona göre yapılmalidir.

140) D. 22, 1, fr. 24, pr. 
edemez: borçlu borcun mevcudiyetini red için bir dava veya exceptio kullanmaya haklı ise hal böyledir. ${ }^{140}$

$2^{\circ}$ ) Borç muaccel olmalıdır.

Borcun muaccel olup olamıyacağ $\breve{g}_{1}$ akitdeki hükümlere ve borç mevzuunun mahiyetine göre tayin olunur: borç ecel veya şarta bă̆h ise, veya ifa müstakbel bir mevzua müteallik ise borçlu ecelin, şartm veya müstakbel mevzuun tahakkuku anına kadar mütemerrid (in mora) addedilemez. Çünkü bu tahakkukdan sonradır ki borç muaccel hale girer ve alacaklı interpellatio'ya hak kazanır.

b) Borçlunun temerrüdü neticeleri :

$\left.1^{\circ}\right)$ Para borcunun alacaklısı ancak mukaveledeki borç mevzuunun yerine getirilmesini isteyebilir. Litis contestatio'ya kadar işleyen faizler dahi talep edilemez. ${ }^{141}$

$2^{\circ}$ ) Mevzuu paradan bașka ve muayyen bir şey olan borcun alacaklı $\mathrm{s}_{1}$ da prensip itibariyle yukardaki kaideye tâbidir. Ancak, debitor in mora) (mütemerrid borçlu) şeyin hasanndan ve kıymet eksikliklerinden mes'uldür. ${ }^{142}$

Borçlu temerrütten sonra kusur haricinde zayi olan şeyi veya be. delini temin ile mükelleftir. ${ }^{143}$ Mamafih, Imparatorluk hukuku temerrüd vaki olmasa idi bile şeyin ziyaa uğrayacağını ispat eden borçluyu bu mükellefiyetten berî kılar. Bu kaide Justinianus hukukunda yalınız Depositum için değil aynî bütün mukavelelere ve hattâ rızai olup da mevzuu bir şeyin tesliminden ibaret bulunan bütün akitlere teşmil olundu. ${ }^{144}$

Müteselsil borçlulardan birinin temerrüdü diğerini mülzem kılmaz; fakat, borçlunun temerrüdü kefile sâridir. ${ }^{145}$

$3^{\circ}$ ) Hüsnüniyet mukavelelerinde mora debitoris'in neticeleri çok farkhıdır: semereler ve geçmiş günler faizi daima ödenir. Mamafih, asıl borç dava ikamesinden evvel ödenmiş ise geçmiş günler faizi ile mükellefiyet mevzubahis değildir. Bu, Roma hukukunda geçmiş günler faiziri

141) Gaius, Inst, II, 280.

142) Dumont, Rev. hist. de droit, 1932, p: 192 et s.

143) D. 45,1, fr. $82,1$.

144) D. 4, 2, fr. $14 ; 30$, fr. 47.

145) R. Monier, Manuel, t. II, p: 294. 
asıl borçla ilgili ihtilâfı halledecek olan hâkimin takdir hakkı ile tayin olunabileceği kaidesinin neticesidir.

\section{B - Mora creditoris. (Alacaklının temerrüdü) :}

Borcun ifa edilmési için yapılan hareketi veya eda teklifini muhik bir sebep olmaksızın kabul etmeyen, veya mecbur iken, ifa ile ilgili hazurlıklan yapmayan alacaklı mütemeriddir.

a) Mora creditoris'in şartlan aynen mora debitoris'in ki gibidir ${ }^{146}$ Binaenaleyh, Klâsik devirde zamanında yapılması lâzım ifayı imkânsı: kılan alacaklı mütemerrid sayılır.

Justinianus devrinde borçlu tarafindan interpellatio da şarttı: ihbar üzerine ifayı kabul etmeyen veya şeyi tesellüm eylemeyen alacaklı mütemerriddir.

b) Alacaklının temerrüdü neticeleri :

$\left.1^{\circ}\right)$ Borçlu, şeyin muhafazası külfetinden kurtulur. Binnetice, şeyin ziyar veya kıymetten düşmesi ancak borçlunun hilesi neticesinde vaki olmușsa borçluyu mülzem kılar. ${ }^{147}$

$2^{\circ}$ ) Mütemerrid alacaklı borçlunun şeyin muhafazası için yaptı̆̆ı masraflan tazmin ile mükelleftir. ${ }^{148}$

$3^{\circ}$ ) Alacaklının temerrüdü borçluyu temerrüdden kurtarır.

Alacaklının temerrüdü bilhassa üzüm ve benzeri şeylerin satışında çok ehemmiyetli idi, öyle ki, bu gibi hallerde her iki tarafın temerrüdü halinde mes'uliyet alacaklıya (müșteri) yükletilmekte idi.149

146) D. 46,3, fr. 72, pr.

147) D. 24,3 , fr. 9.

148) Satılan kölenin bakımı bilhassa iaşesi için yapılan masraf tazmin edilmeli idi: D. 19,1 , fr.

149) D. 18,6, fr. 4,2 . itp, infine. 